Article

\title{
The Reincarnation(s) of Jaya and Vijaya: A Journey through the Yugas
}

\author{
Steven J. Rosen \\ Journal of Vaishnava Studies, New York, NY, USA; stevenrosen32@yahoo.com
}

Received: 31 July 2017; Accepted: 31 August 2017; Published: 4 September 2017

\begin{abstract}
Among the earliest reincarnation narratives found in India's Puranic texts, we find the stories of Jaya and Vijaya, the two gatekeepers of the spiritual world. Though there is little in these stories to explain reincarnation in a philosophical sense, the teaching of transmigration is implicit in the stories themselves, for we follow the two gatekeepers through three successive incarnations (along with the three incarnations of the divine who follow them through their various lifetimes).
\end{abstract}

Keywords: reincarnation; Jaya and Vijaya; Narasimhadeva (Nṛsimha); Rāma; Krishna; Avatāra; Śrīmad Bhāgavatam; Śrī Chaitanya; yuga

Reincarnation, of course, is accepted as a given in India's mystical literature, and, according to Eastern sensibility, its truth undergirds any genuine metaphysical understanding of life. We are spirit-soul, say texts like the Bhagavad-git $\bar{a}(2.13,21,22$, among others), and not the material body. We are a quantum of energy, and energy, we learn from the natural sciences, is never created or destroyed. It continues to exist in some form. God, too, is spiritual substance, and $\mathrm{He} / \mathrm{She} / \mathrm{It}$ reincarnates as well. ${ }^{1}$ But whereas regular souls are forced to incarnate according to their karmic activity-for every action there is an equal and commensurate reaction-God appears in various forms according to His sweet will, for the sake of play $(l \bar{l} l \bar{a})$ and to educate.

This paper will focus on three such incarnations of the Supreme-three of His most important manifestations-and, alongside those appearances of divinity, we will discuss three incarnations of ordinary beings who challenged the Lord and battled Him to the "death."

The three incarnations of the Divine, in the order in which they appeared in the material world, are Nṛsimha, Rāma, and Krishna. Confidential wisdom texts of India describe them as Parāvastha Avatāras, or "perfect" incarnations. The Śrimmad Bhägavatam (1.3.26), known as the "ripened fruit" of the Vedic tree of knowledge, tells us that: "... the incarnations of the Lord are innumerable, like rivulets flowing from inexhaustible sources of water." Normally, all of these incarnations are considered equal, as just various forms of one divine being, and yet, according to the Padma Purāna (Uttara 226.42), ${ }^{2}$ the three mentioned here are singled out as most important, as embodying the ultimate and most complete form of divinity.

For the Gaudīya Vaishnava tradition, this is confirmed in Rūpa Goswāmī's Śrī Laghu-bhāgavatāmṛta (1.5.16-64), where he echoes the Padma Purāna and adds that Krishna, in particular, is avatār $\bar{\imath}$, or the source of all incarnations (Laghu-bhägavatāmrta, 1.5.303-7). We will return to this concept of Parāvastha Avatāras, with special attention to Krishna's supreme position, after following the ongoing narrative of Jaya and Vijaya, the two gatekeepers of the spiritual world.

1 The word "incarnation" or even "reincarnation" when referring to God is used simply as a matter of convenience. While ordinary souls incarnate in terms of taking on a material body (the word incarnate literally refers to being clothed in a "carnal" or fleshy form), God is always spiritual, and His "body" is never composed of material elements.

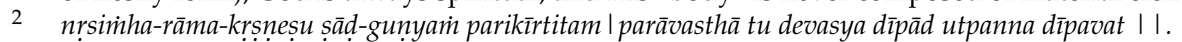




\section{Jaya and Vijaya}

As the story goes, there were once four little boys, the Kumāras, who tried to gain entrance into Paradise, the spiritual world, known in the Indic tradition as Vaikuntha. ${ }^{3}$ Though they looked like five year olds, they were actually very old and spiritually very advanced-but not advanced enough. At the entrance to Paradise were two gatekeepers whose names were Jaya and Vijaya, and it was their job to allow or prevent, as the case may be, living beings who propose to enter.

Now, these four little boys, though spiritually advanced, were impersonalists. ${ }^{4}$ According to Vaishnava tradition, an impersonalist is someone who thinks of God as not having form and is thus not ready to enter the spiritual world, where one has sweet interaction and relationship with God's form. Because of this, when the four little boys tried to enter Paradise, the gatekeepers, Jaya and Vijaya, stopped them from doing so.

As little boys often do, the Kumāras became angry for not getting their way, and they placed a curse on the two gatekeepers, forcing them to take birth in the material world. ${ }^{5}$

Immediately fearing for their own well being, Jaya and Vijaya asked the four little boys for forgiveness, and it was at that moment when the Supreme Person Himself-Vishnu-appeared on the scene to intervene on their behalf. ${ }^{6}$ Placating the small boys, Vishnu convinced them to allow Jaya and Vijaya, as penance for their offense, to, yes, take birth in the material world, but, after some time, to return to Vaikuntha, the spiritual realm. With that being said, the two gatekeepers lost their effulgence. Their countenances having fallen and becoming deeply saddened, they fell to the material world, taking birth as demons. ${ }^{7}$

\section{Hiranyākṣa and Hiranyakaśipu}

We will now see Jaya and Vijaya take three births each throughout cosmic history-in each part of the world cycles, that is, in each of the initial three yugas - and then a very special birth in the fourth. Jaya becomes Hiranyaksha, Rāvana, and Sishupala ${ }^{8}$ in Satya-, Treta-, and Dvāparā-yuga, respectively. ${ }^{9}$ The sequence for Vijaya similarly manifests as Hiranyakaśipu, Kumbhakarṇa, and Dantavakra. ${ }^{10}$ Though this might seem a little confusing, we will now see how it all plays out.

Once, millions of years ago, twins were born. ${ }^{11}$ Their names were Hiranyākssa and Hiranyakaśipu. The former means "one who loves gold and does his best to look for it, mine it, and collect it," and the latter means "one who loves gold and soft bedding," with the latter point subtly referring to a desire for sexual pleasure. ${ }^{12}$

In other words, both Jaya and Vijaya, in their births as Hiranyākṣa and Hiranyakaśipu, were of unfortunate mentality, rascals who were always looking for material comforts as well as always

3 This story of the gatekeepers can be found in numerous Puranic texts. This version is found in A. C. Bhaktivedanta Swami Prabhupada, Śrīmad-Bhāgavatam (SB) (Prabhupada 1977-1982), beginning with Canto 3, Chapter 15, Text 12. Similar "gatekeeper" stories can be found in other religious traditions. For example, in the Christian tradition, St. Peter has often been depicted as "holding the keys" to Paradise, and in Islam, to cite one other example, we learn of heaven (Jannah) as having eight doors or gates.

4 Ibid., 3.15.33, 43.

5 Ibid., 3.15.34.

$6 \quad$ Ibid., 3.15.37.

7 Ibid., 3.16.33

8 http://www.vedabase.com/en/mbk/appendix-5-main-characters.

9 SB 10.74 .46 Purport.

10 Ibid., 7.1.35. Purport. Tradition holds that Vishnu gave Jaya and Vijaya an option to choose one or the other, i.e., seven births as devotees or three births as demons and that Jaya and Vijaya chose the latter. One will not find, however, any real scriptural evidence for this. The closest reference would be SB 7.8.56, purport, where Prabhupāda writes, "Jaya and Vijaya were very much perturbed, but the Lord advised them to act as enemies, for then they would return after three births; otherwise, ordinarily, they would have to take seven births."

11 Ibid., 3.17.2.

12 Ísopaniṣad, Translation and explanation by Prabhupāda (Los Angeles: Bhaktivedanta Book Trust, 1970). 
challenging the Supreme Person. ${ }^{13}$ While such a mindset is normally an impediment to bhakti, or devotional service, it was in this instance the result of God's will, as we shall see. ${ }^{14}$

Because of the elder brother Hiranyākṣa's constant desire to mine for gold in the Earth, our planet gradually became unstable and detached from its position of floating in the universe. Thus, she eventually fell down into the cosmic ocean. ${ }^{15}$

Meanwhile, Hiranyākṣa underwent tremendous austerities and thus received the blessings of Brahmā, the first created being, who allowed him to become undefeatable by man or beast. In due course, Hiranyākṣa took the Earth, already loosened by his mining activity, as already noted, and plunged her into the primordial depths of the cosmic ocean. All seemed lost.

However, when procuring his boon from Brahmā, Hiranyākṣa had not mentioned the boar in his list of animals that would not be able to conquer him, and in light of this, Vishnu assumed just that form-Varāha Avatāra-with huge tusks and other assorted boar features. Diving down into the primordial ocean, he saved the earth as only a boar could, lifting it up with His transcendental tusks. But while in the ocean, He encountered Hiranyākșa, who was ready for combat. They charged toward each other with rage. Finally, after a thousand cosmic years of battle, Hiranyākṣa was slain, ready for his next birth.

Although both Hiranyākṣa and Hiranyakaśipu received the blessing that they would never be killed by any living being in the universe, ${ }^{16}$ Hiranyakaśipu asked for additional boons from Lord Brahmā. Specifically, he wanted to become totally immortal, but Brahmā said that even he could not overcome death and consequently could not grant such freedom to Hiranyakaśipu.

Hiranyakaśipu then tried to circumvent this obstacle: He asked that he not be killed by any man, animal, god or, in fact, anyone in the material universe. He also asked that he not die on land, in the air, water, nor by any weapon. ${ }^{17}$ Lastly, he asked that he not be killed in the daytime or nighttime. ${ }^{18}$ He thought that this would effectively make him unconquerable. Brahmā granted him these boons.

Now, Hiranyakaśipu was angry with Vishnu for killing his brother Hiranyākṣa and it was in his anger that he asked Lord Brahmā for the above blessings, hoping to use his invulnerability to destroy the Earth's saintly culture and to subjugate the entire universe-what to speak of destroy Vishnu Himself. ${ }^{19}$ More, he had legions of followers to assist him in his ugly plan, and they were only too glad to carry out his orders.

"Thus the demons, being fond of disastrous activities, took Hiranyakaśipu's instructions on their heads with great respect and offered him obeisances. According to his directions, they engaged in envious activities directed against all living beings." (SB 7.2.13)

And yet, in spite of all his wealth and influence, all his endeavors to "overturn the established practices within [the] world, ${ }^{\prime 20}$ to conquer the universe and planets of all human beings and bring them under his control, along with all his opulence and power, ${ }^{21}$ bodily strength, and enjoying all types of sense gratification as much as possible, ${ }^{22}$ ultimately he failed and was killed by the Supreme Person ${ }^{23}$-Nrisimhadeva, the half-man/half-lion incarnation, battled with him and ripped him to shreds.

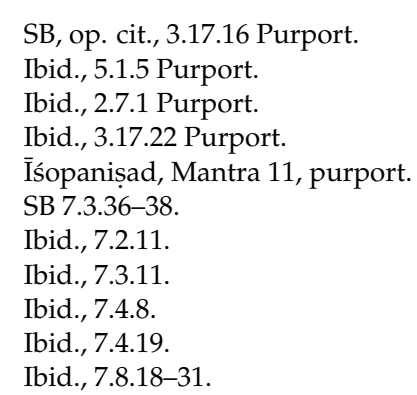


To fulfill the benedictions given to him by Lord Brahmā, Hiranyakaśipu was killed after he had been placed on Nrsimha's lap and therefore not by any created being; during dusk and therefore not during day nor night; not inside or out but on the terrace, and on the lap of the Lord; wasn't killed by any "person" but by an incarnation of God; and not by any manmade weapon, ${ }^{24}$ but by the claws of Nṛsimha, the Supreme Person Himself.

\section{Rāvaṇa and Kumbhakarṇa}

Rāvana and Kumbhakarṇa, the second incarnations of Jaya and Vijaya, were rākṣasas-demons who ate humans - and were brothers born into the family of Viśravā and Keśinī. Rāvana means "one who causes trouble for others and makes others cry," 25 and it is said that he was a ten-headed monster-literally. Kumbhakarna, the younger brother of Rāvaṇa, means "pot-eared," and he was called this specifically because of the shape of his ears. Kumbhakarna, we are told, slept a lot and upon waking had a big appetite- for people. ${ }^{26}$

The story of the two rākșasa brothers is predominantly found in the Rāmāyana-an ancient Indian epic of approximately 24,000 Sanskrit verses-and in the 9th Canto, Chapter 10 of Srimad-Bhāgavatam, among other places. In any case, the point is this: Rāvana wasn't able to control himself; he was a demon of the worst order, setting any kind and altruistic ideas aside in favor of self-aggrandizement and complete selfishness. He apparently had lusty desires for Rāma's wife Sītā, too, who he kidnapped by subterfuge and took to Lanka. ${ }^{27}$ Kumbhakarna was similarly uncontrolled. He is briefly mentioned in SB 9.10.18, and in the 7th, 4th, and 9th Cantos, but it is usually only in passing.

There's more information about Kumbhakarna in the Rāmāyana, but even that seems negligible. Another source has Kumbhakarṇa telling Rāvana that the way he abducted Sìtā wasn't proper (Narayan 2006, p. 125). That same source tells how it was difficult to arouse Kumbhakarna from his deep sleep ${ }^{28}$ and that if you were the one unfortunate enough to be given the task of awakening him, you would likely end up becoming his breakfast.

Rāvaṇa and Kumbhakarṇa were later killed by Lord Rāma, the incarnation of Vishnu in the Tretā age. First Kumbhakarna was killed, but not before he killed thousands of the monkey warriors of Hanumān's brother's army. ${ }^{29}$ As for Rāvana, he was killed in Lanka ${ }^{30}$ when Rāma shot an arrow into his heart. ${ }^{31}$ The fatal blow had to be in his heart because he had been given a benediction that if any of his ten heads were destroyed, another would take its place. ${ }^{32}$ Interestingly, Rāvana's original nature came through after he was killed by Rāma.

"Rama's arrows had burnt off the layers of dross, the anger, conceit, cruelty, lust, and egotism which had encrusted his real self, and now his personality came through in its pristine form ... "33

\section{4. Śiśupāla and Dantavakra}

For their third (and ostensibly last) incarnation, Jaya and Vijaya took birth in a kșatriya family as the cousins of Yudhișthira. ${ }^{34}$ Oddly, Siśupāla is said to have had three eyes and four arms when he was born. ${ }^{35}$ He was the son of Damaghoṣa (Prabhupada 1972-2010, p. 356), later became the King

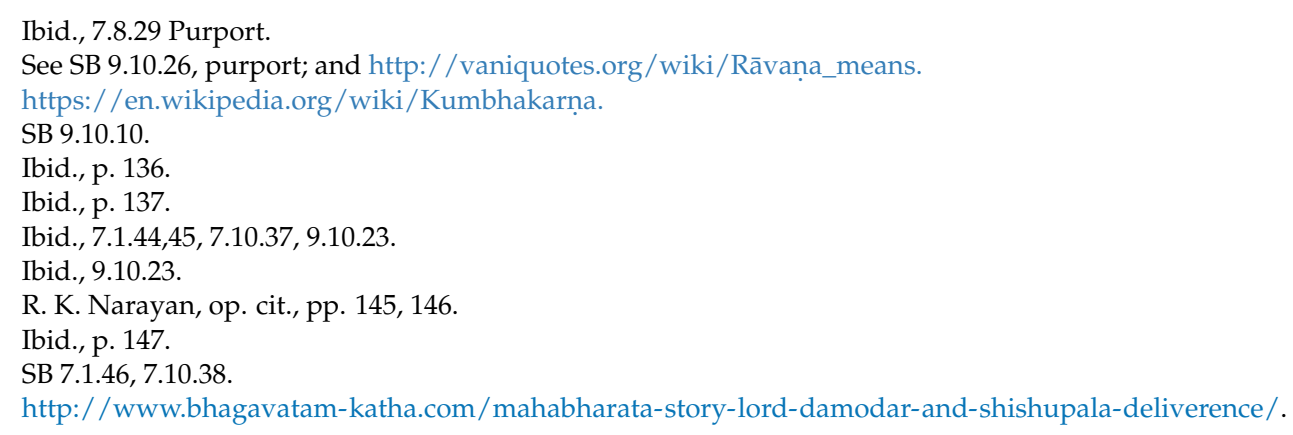


of Chedi, a kingdom in ancient India, and was an enemy of Krishna. Śiśupāla's cousin, Dantavakra (they weren't brothers in this birth) was so named because of his crooked teeth ${ }^{36}$ and he was the king of Karūșa. ${ }^{37}$

Both Śiśupāla and Dantavakra were killed by Krishna, ${ }^{38}$ with the first being Śiśupāla. It happened that King Yudhisthira decided to have a big consecration ceremony and invited all the demigods and qualified Brahmins to attend. ${ }^{39} \mathrm{He}$ also invited other family members who were less than qualified. One of them was Śiśupāla, who was also one of Krishna's cousins. He was angry with Krishna for many reasons, but one of them was that he, Śiśupāla, was supposed to marry Princess Rukminī and the very day of her wedding, Krishna kidnapped her as per her desire and she married Him instead. ${ }^{40}$

Back to Yudhisthira's ceremony: The most important people of the clan were invited to speak, and when it came to Śiśupāla's turn, he remained seated which in itself was disrespectful, and, then, what's worse, he began to berate Krishna. Siśupāla didn't just give his opinion about things-he suggested that Krishna wasn't fit to be honored the way the others were honoring Him. He kept going on and on and became more and more offensive as he continued. ${ }^{41}$ Some of those present actually covered their ears or left the assembly. Others were so offended by Śiśupāla's words that they threatened to kill him. It was then that Krishna, seeing that the ceremony was about to be disrupted, threw his Sudarśana chakra at Śiśupāla, cutting his head off-giving him liberation. ${ }^{42}$

After Śiśupāla's death, Dantavakra became extremely angry and in his anger challenged Krishna to battle, bringing only his anger and a single club to the fray. Krishna, following the rules of military etiquette, armed Himself in a commensurate way, using only a club. As is usual for a demon, Dantavakra hurled meaningless insults at Krishna. Then they fought.

At first he tried to placate the Lord by reminding Him that they were cousins, but then he started to boast again, saying he would tear Krishna into pieces. Just then, he hit Krishna in the head with his club, and not feeling any pain or discomfort, Krishna retaliated by hitting Dantavakra in the chest, splitting his heart wide open. ${ }^{43}$ Those present at the confrontation say they saw a small spiritual spark go from Dantavakra's body into Krishna's.

This birth was special for Jaya and Vijaya.

According to Rūpa Goswāmī's Laghu-bhāgavatāmṛta (1.5.41-64), the order of births in which Jaya and Vijaya were killed is significant. In their first birth as Hiranyākṣa and Hiranyakaśipu, they did not realize that Varāha and Nṛsimha were Vishnu. They weren't conscious of who it was they were battling with. Similarly, as Rāvaṇa and Kumbhakarṇa, they didn't know who Lord Rāma really was.

However, in their maturity, having evolved over two prior births, things were different. As Siśupāla and Dantavakra, they were able to perceive that Krishna was in fact the Supreme Lord. More, due to their growing hatred of Him over the two prior lifetimes, they consistently chanted His names, if, unfortunately, in disgust, and that too led to their liberation, so holy is His name. Therefore, as Śiśupāla and Dantavakra, they are described as attaining supreme release. But they did not immediately go to the spiritual world, to be reinstated as the eternal gatekeepers of Vaikuntha. First, they were to undergo one more incarnation—one that would bestow upon them special mercy.

\section{Liberation of Jāgai and Mādhāi}

In Kali-yuga, the fourth age cycle in which we currently exist, there is a special incarnation of Krishna who not only partakes of His supreme position as avatāri , thus allowing Him to be counted

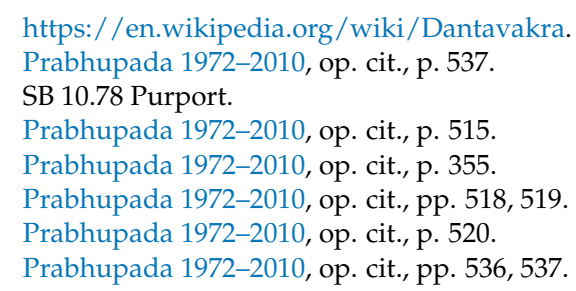


amongst the Parāvastha Avatāras, but who has the esoteric dimension of being Krishna in the mood of Rādhā, the female Absolute. This means that He is essentially not only God but also an incarnation of Love Supreme. $^{44}$

This dynamic and confidential avatāra is Śrī Chaitanya, appearing on Earth some 500 years ago in Bengal, India.

On one occasion pertinent to our discussion, He asked His chief associates, Nityānanda and Haridāsa: "Please go through the streets of Navadvip, door to door, and ask one and all to sing the name of Hari with devotion." ${ }^{\prime 4}$ The two enthusiastic preachers went out on the Lord's behalf and accomplished miracles. Soon they met Jagāi and Mādhāi, two wayward Brahmin brothers. Sacred texts tell us that these brothers were the fourth and final incarnation of Jaya and Vijaya. ${ }^{46}$

Addicted to wine and women, Vaishnava texts describe them as debauchees of the worst caliber. When Nityānanda and Haridāsa confronted them, the two missionaries were ridiculed, with Jagāi and Mādhāi saying that they were fools to work on Śrī Chaitanya's behalf.

The two brothers further showed their lack of character by shouting obscenities at Nityānanda and chasing him down the street. Thankfully, the unseemly incident was prematurely aborted, and no harm was done. When Śrī Chaitanya learned later that day that Nityānanda had attempted to preach to such wayward individuals, He commended him.

The next day, however, Nityānanda tried again, but this time it would not end so easily. As soon as he approached the iniquitous brothers, Mādhāi had the audacity to throw a piece of broken pot at him. And when it reached its target, it slightly pierced Nityānanda's forehead, causing blood to flow. He was not swayed. Despite the injury, he quickly forgave them, insisting that they chant the holy name.

Jagāi was impressed. He had never seen such compassion. Nityānanda was clearly in a category of his own, an embodiment of love. As this realization made its home in Jagāi's heart, he began to beseech Nityānanda to excuse his foolish brother. But it was clear from Nityānanda's merciful glance that the pardon was already in effect. Nonetheless, Madhāi was about to cause Nityānanda more pain. Jagai, however, would not tolerate it, and he stopped him, insisting that they both surrender to Nityānanda Prabhu.

In the midst of this exchange, Śrī Chaitanya suddenly appeared on the scene, furious that someone had offended his dear devotees. Raising His arm in the air to summon His famous weapon-the disc of Vishnu-He prepared to kill the two offenders. Just at that moment, however, Nityānanda stepped in, insisting that the Lord show mercy. He reminded Him of His mission to liberate the most sinful, which was one of the purposes of the Chaitanya incarnation. In essence, Nityānanda reminded him that His was a mission of love, and that the only killing would be that of the demoniac mentality, not a literal taking of life. Nearly everyone in this age, said Nityānanda, is comparable to Jagāi and Mādhāi. To be consistent, wouldn't Śrī Chaitanya have to kill everybody?

44 See Śrī Caitanya-caritāmṛta, Ādi 7.9: “Lord Krishna Himself appeared as Śrī Chaitanya Mahāprabhu with all His eternal associates, who are equally glorious." (sei krṣna avatīrna śri-krṣna-caitanyasei parikara-gana sañge saba dhanya) Also see Caitanya-caritāmṛta, Ādi 4.55: "The love of Śrī Rādhā and Krishna are spiritual aspects of the Lord's internal pleasure potency. Although Rādhā and Krishna are one supreme entity, they separate eternally as two to enjoy the relish of relationship. Now, in the form of Śrī Krishna Chaitanya, these two Supreme entities have again united. I thus bow down to Him, who appears with the sentiment and complexion of Rādhikā even though He is Krishna Himself." (rādhā krṣna-pranaya-vikrtir hlādin̄̄ śaktir asmādekātmānāv api bhuvi purā deha-bhedam' gatau taucaitanyākhyami prakațam adhunā tad-dvayam' caikyam āptamírādhā-bhāva-dyuti-suvalitamí naumi krṣna-svarūpam).

45 See Bhaktivinoda Thakura's Sri Chaitanya: His Life and Precepts. (http://www.purebhakti.com/mission/bhakti-is-lovemainmenu-75/799-life-of-sri-chaitanya-mahaprabhu.html).

46 The tradition's textual source for claiming that Jagāi and Mādhāi were a fourth incarnation of Jaya and Vijaya can be traced to the Śrī Gaura-ganoddeśa-dīpikā (115): "Jaya and Vijaya, the two doorkeepers of the spiritual world, voluntarily appeared in Śrī Chaitanya's pastimes as the two devotees Śrī Jagannātha and Śrī Madhava." These latter names were awarded to Jagāi and Mādhāi after they converted to Vaishnavism. 
Contemplating the words of his dear devotee, Chaitanya accepted Jagāi and Mādhāi as His own, but only on the condition that they reform their behavior. The brothers agreed and became devoted followers of Śrī Chaitanya's movement.

\section{Conclusions}

While Jaya and Vijaya were given three births as demons with which to learn their lesson and return to the spiritual world, we see that God, in His infinite compassion, gave them yet another birth in which they could achieve the highest level of liberation.

Generally, in Hindu culture, we learn of the purusārthas, that is, the four goals of man: dharma (religious duty, moral values), artha (prosperity, economic development), kāma (pleasure, love, sense gratification) and mokșa (liberation from material existence). Most people go through a progression over many lives to attain mokșa, or liberation. They evolve through levels of consciousness in the $8,400,000$ species of life mentioned in Vedic texts, and when they come to the human form, the Puranic texts tell us, they often spend their lives like Jagāis and Mādhāis, in a nearly subhuman state of consciousness.

Through the hard knocks of life and little grace, perhaps, they gradually see the importance of religious activity, or dharma, and due to pious engagement, they may experience some prosperity as a result of their good karma (action/reaction schema). Even here, however, they usually squander their good fortune for sense gratification (kâma), and get lost again in the whirlpool of material existence.

Still, a fortunate few will use their good fortune to pursue liberation from material life (moksa), and by the grace of holy association and good sense, they may achieve some level of spiritual accomplishment. And if they perfect that, they may know true liberation from material existence. This is the highest attainment in most Hindu traditions.

That being said, Śrī Chaitanya came to give a fifth purușārtha, which is known as premā, divine love. This surpasses mokșa, or, let us say, it is the highest form of mokșa. By the grace of a pure devotee of the Lord, one may attain this higher destination, but it is rarely achieved.

Due to their fortunate interaction with Śrī Chaitanya and Nityānanda Prabhu, Jagāi and Mādhāi were able to attain such premā, thus liberating their real selves-Jaya and Vijaya-in the highest possible sense. This indeed is the perfection of reincarnation and of the entire spiritual pursuit.

Conflicts of Interest: The author declares no conflict of interest.

\section{References}

Narayan, Rasipuram Krishnaswami. 2006. The Ramayana, a Shortened Modern Prose Version of the Indian Epic. London: Penguin Classics. First published 1972.

Prabhupada, A. C. Bhaktivedanta Swami. 1972-2010. Krsna, The Supreme Personality of Godhead, A Summary Study of Srila Vyasadeva's Srimad-Bhagavatam, Tenth Canto. Los Angeles: Krishna Bhaktivedanta Book Trust.

Prabhupada, A. C. Bhaktivedanta Swami. 1977-1982. Śrīmad-Bhāgavatam (SB). Los Angeles: Bhaktivedanta Book Trust. 